\title{
Village Fund Management in Public Sector Accounting System: Case from East Indonesian Region
}

\author{
Jenny Morasa $^{1}$, I Gede Suwetja ${ }^{2}$, Syermi S. E. Mintalangi ${ }^{3}$ \\ Sam Ratulangi University Faculty of Economy and Business, Manado Indonesia ${ }^{1,2,3,4}$ \\ \{jennymorasa@unsrat.ac.id ${ }^{1}$,suwetjagede1976@unsrat.ac.id², msyermi@unsrat.ac.id ${ }^{3}$ \}
}

\begin{abstract}
The management of village funds is part of a country's public sector accounting system, particularly for village development, supporting the economy, new public management implementation, and good governance reform in emerging countries. This article is empirical research in the form of a qualitative study of village fund management in the Republic of Indonesia based on the prevailing laws and regulations. The research method was descriptive qualitative with a phenomenological approach focused on villages in Kumelembuai District, South Minahasa Regency, North Sulawesi Province. This research's findings include that village fund management has been well managed under applicable laws and regulations. Suggestions in this study are in the form of things that need to be done by local and central governments in Indonesia to create sustainable success from the management of this village fund. The implications, as well as the limitations of the study, are discussed in this article.
\end{abstract}

Keywords: Village Fund; New Public Management; Public Sector Accounting System; Good Governance; North Sulawesi; Indonesia

\section{Introduction}

The New Public Management (NPM) movement emerged in the late 1970s and early 1980s [1]. This concept refers to the framework of the paradigm of public sector modernization, especially strengthening the relationship between government and civil society [2] which plays a role in how well government works [3]. The emergence of NPM was mainly due to the community's public bureaucracy problems, such as rampant red tape, unpleasant official, poor service, and corrupt practices [4]. Dramatic changes around the world in both developed, emerging and developing countries [5]. The need for a public sector order that is clean, transparent and accountable [6] encourages the application of the NPM concept worldwide. The successful implementation of NPM in many countries, such as OECD countries [7] has made this NPM popular, especially in the financial and public sector accounting [8].

The implementation of NPM in the public financial sector is one of the main goals of public sector governance [9]. The effectiveness of the public sector entity is aimed at actually achieving its mission, which in public sector accounting includes the process of recording, analyzing, classifying, summarizing, communicating, and interpreting financial information 
about Government, recording all transactions of public funds and property [10]. NPM implemented in a quality manner in public sector governance is the key to public sector accounting reform, especially improving accountability, transparency of decision making, interest representation, conflict resolution mechanisms, the rule of law, citizens' participation, and civil liberties [11].

In Indonesia, the public sector accounting system is part of the public sector movement [12] in the 1980s [13], and the adoption of this system was motivated by NPM philosophy [14]. The initiation of public sector reform has been even stronger since the Asian currency crisis in 1998. Regulations regarding the change to NPM began when the government issued [15]: Law no. 17/2003 on State Finance, Law no. 1/2004 concerning the State Treasury no. 15/2004 concerning Audit of State Financial Management and Accountability. The full accrual accounting system in government began in 2005 and 2010 by the Government Regulation of Governmental Accounting Standard (GAS), namely GAS No. 24/2005 [16], and GAS No. 71/2010 [17], where the public sector accounting system previously referred to the Dutch Government framework when they colonized Indonesia before Independence 1945 [14].

One part of the implementation of the public sector accounting system in Indonesia is the village fund program. Village fund known as Village Fund Allocation or Village Fund Allocation (ADD) is one of the Indonesian Government's leading programs to accelerate poverty alleviation in the country [18]. This program is a mandate of Law No. 6/2016 on Village, where the village has the authority to manage village resources independently for village development. This program has been implemented since 2015, despite leaving many problems and challenges, this program has succeeded in encouraging a lot of progress in the village, such as the construction of infrastructures such as roads, bridges, schools, buildings, and health facilities [19].

Several studies on village fund management have been carried out by researchers such as the Imawan \& Purwanto research [20] using the impact assessment concepts with quantitative methods. Researchers found that there has been an increase in village facilities, infrastructures, and community empowerment programs. However, there are problems found in the form of the not optimal equalization and utilization of Indonesia's village funds. Nurhakim \& Yudianto's research [21] using a qualitative method found that the implementation of village fund management starting from planning, implementation, administration, reporting, and accountability in villages on the island of Java, namely in Bandung Regency is appropriate with the regulation of village fund management. However, there are also inappropriate, such as administration that is not under regulations, and reporting that is not on time.

Research on village funds which is still emerging requires a deeper and broader study at various places in Indonesia to understand its implications and progress. One of the still rarely done things is the management of village funds in the East Indonesian Region, which is still behind compared to the West Indonesian Region (22). For this reason, it is necessary to conduct village fund management research in villages in this region in village management funds that are following applicable laws and regulations in the context of implementing public sector accounting reform and the adoption of the NPM paradigm in Indonesia.

This article is an empirical study of village funds in the public sector accounting in Indonesia. The research focuses on village fund management, while the research locus is in villages in the East Indonesian Region. This article is divided into several sections, such as an introduction, literature review, methods, results, discussion, and conclusions. Some of the implications and limitations are also discussed in this article. 


\section{Literature Review}

\subsection{New Public Management}

The adoption of NPM in many OECD countries occurred during the 1980s. This change in public management is called accounting, accepting the doctrine of public accountability and public administration [23]. NPM is a public management theory which assumes that private sector management practices are better than public sector management practices. Therefore, to improve the public sector's performance, it is necessary to adopt several management practices and techniques applied in the private sector, for example, those related to market mechanisms, Compulsory Competitive Tendering, and privatization of public companies [24].

The application of NPM is seen as a form of management reform, depoliticization of power or decentralization of authority that promotes democracy. The changes started from rethinking government and continued with reinventing government (including reinventing local government) which changed the role of government, especially in terms of governmentto-community relations. Theoretical changes, for example, from public administration to public management, the reduction of government bureaucracy and the contract system's use throughout the world, although the details of the reforms vary. Trends in almost every country are towards the use of performance-based budgets, outcome-based management, and accrual accounting. NPM is a global phenomenon; however, its application may vary depending on localized contingencies [25].

According to Hood [23], although some NPM writers emphasize different aspects of the NPM doctrine, there are seven aspects summarized. The seven aspects are as follows [25]: (1) Professional management in the public sector. (2) The existence of performance standards and performance measures. (3) Greater emphasis on outputs and outcomes. (4) The breakdown of work units in the public sector. (5) Creating competition in the public sector. (6) Adoption of business sector management to the public sector. (7) Emphasis on discipline and greater savings in the use of resources.

\subsection{Public Sector Accounting}

According to Mardiasmo [26]. Public sector accounting has various meanings. This is a consequence of the vastness of the public sphere so that each scientific discipline (economics, politics, law, and society) has different perspectives and definitions. From the perspective of economics, the public sector can be understood as an entity whose activities are related to the effort to produce public goods and services to fulfil the public's needs and rights. Produce public goods and services. In this case, public sector accounting is different from private sector accounting, but the function of the public sector can actually be carried out by the private sector, for example, the task of producing several types of services, such as communication services, tax collection, education, public transportation, and so on [26].

The American Accounting Association [27] states that the role of accounting in public sector organizations is to: (1) Provide the information needed to manage appropriately, efficiently, and economically for an operation and the allocation of resources entrusted to the organization; (2) Providing information that enables managers to report on the implementation of the responsibility for managing appropriately and effectively the program and the use of data sources under their authority; and allows government employees to report to the public the results of government operations and the use of public funds. Public sector accounting is related to three main things, namely Information Provision, Management Control and 
Accountability. Information for the public. For the government, accounting information is used in the management control process, starting from strategic planning, programming, budgeting, performance evaluation, and performance reporting.

\subsection{Regional Sector Financial Management}

Regional financial management is often interpreted as mobilizing financial resources owned by a region. This viewpoint is oversimplifying and tends to result in reactive and unilateral policy recommendations. For adherents of this view, regional autonomy will be difficult to materialize because the available financing sources for the autonomous regions are very "thin in terms of quality." In contrast, from a quantity point of view, these sources of financing are minimal. Meanwhile, according to Halim [28], Regional Finance can be defined as: "All rights and obligations that can be valued in money, as well as all units, both in the form of money and goods, which can be used as regional assets as long as they are not owned or controlled by a more powerful state or region, and other parties under the provisions of the applicable laws and regulations.

In a broader concept, the Regional Financial Management System consists of the following aspects [29]: (1) Management (optimization and/or balancing) of all sources capable of providing revenue, income, and/or possible savings. (2) Determined by the Executive Board and Legislative Body, implemented by the Executive Board, and supervised by the Legislative Body and all regional society components. (3) Directed for the welfare of the entire community. Based on the principles of economics, efficiency, and effectiveness. (4) Documentation, transparency, and accountability.

\subsection{Village Fund}

According to Law no. 6 of 2014, Village is a village and customary village or what is referred to by other names; according to Law no. 6 of 2014, Village is a village and customary village or what is referred to by other names, hereinafter referred to as Desa, is a legal community unit that has territorial boundaries that are authorized to regulate and administer government affairs, the interests of the local community based on community initiative, rights of origin, and/or traditional rights recognized and respected in the government system of the Republic of Indonesia. The village has the right to regulate its wider territory. In order to regulate and manage the interests of its community, the village has the authority, namely [18]: (1) Carry out existing government affairs based on the rights of village proposals; (2) Carrying out government affairs which fall under the authority of regencies/cities which are delegated to the village administrators, namely government affairs which can directly improve community services. (3) Assistance tasks from the government, provincial government, and district/city government. (4) Government affairs others were handed over to the village.

According to the Regulation of the Minister of Finance Number 49 of 2016 concerning the management, distribution, use, monitoring, and evaluation of Village Funds, Village Funds are funds sourced from the State Revenue and Expenditure Budget for villages that are transferred through the district/city Regional Revenue and Expenditure Budget. and used to finance governance, development implementation, community development, and community empowerment.

The management of Village Funds in Presidential Regulation No. 60 concerning Village Funds article 2 states that Village Funds are managed in an orderly manner, obeying the provisions of laws and regulations, are efficient, economical, transparent, and responsible by 
taking into account the sense of justice and appropriateness and prioritizing the interests of the local community. As for the Regulation of the Minister of Finance Number 49 concerning Procedures for Allocation, Distribution, Use, Monitoring and Evaluation of Village Funds article 22 paragraph 2, it is stated that the implementation of activities financed by the Village Fund is prioritized to be self-managed by using local resources or raw materials, and is pursued with more absorption. Workers from the local village community, referred to as Desa, is a legal community unit that has territorial boundaries that are authorized to regulate and administer government affairs, the interests of the local community based on community initiative, rights of origin, and/or traditional rights recognized and respected in the government system of the Republic of Indonesia.

The village has the right to regulate its wider territory. In order to regulate and manage the interests of its community, the village has the authority, namely [18]: (1) Carry out existing government affairs based on the rights of village proposals; (2) Carrying out government affairs which fall under the authority of regencies/cities which are delegated to the village administrators, namely government affairs which can directly improve community services. (3) Assistance tasks from the government, provincial government, and district/city government. (4) Government affairs others were handed over to the village.

According to the Regulation of the Minister of Finance Number 49 of 2016 concerning the management, distribution, use, monitoring, and evaluation of Village Funds, Village Funds are funds sourced from the State Revenue and Expenditure Budget for villages that are transferred through the district/city Regional Revenue and Expenditure Budget and used to finance governance, development implementation, community development, and community empowerment.

The management of Village Funds in Presidential Regulation No. 60 concerning Village Funds article 2 states that Village Funds are managed in an orderly manner, obeying the provisions of laws and regulations, are efficient, economical, transparent, and responsible by taking into account the sense of justice and appropriateness and prioritizing the interests of the local community. As for the Regulation of the Minister of Finance Number 49 concerning Procedures for Allocation, Distribution, Use, Monitoring and Evaluation of Village Funds article 22 paragraph 2, it is stated that the implementation of activities financed by the Village Fund is prioritized to be self-managed by using local resources/raw materials, and is pursued with more absorption, workers from the local village community.

\section{Methodology}

This study uses a qualitative descriptive method with a phenomenological approach [30]. Phenomenology seeks to uncover and study and understand a phenomenon and its unique and unique context experienced by individuals up to the individual concerned's "belief." The phenomenology in this study focuses on public sector accounting on local government financial management, especially the meaning of village funds managed by the local government where the research is conducted [31].

The research location is in Kumelembuai District, South Minahasa District, North Sulawesi Province. The research data is primary data that takes a real picture of the phenomenon of village fund management in Indonesia with the cases of villages in Kumelembuai District, South Minahasa Regency. The number of villages studied was 8 villages, research in interviews, and direct observations into the field. The research focuses on village fund management under Law No. 6/2014 and Government Regulation 60/2014. Key 
informants include the camat, the Hukum Tua (village head), village officials, BPD, LMD, community leaders, village communities, a total of 10 informants, 8 from 8 villages, and 2 people from the sub-district office.

\section{Results and Discussion}

The Village Implementation Team carries out the implementation of activities whose funding comes from the Village Fund. To support transparency and the delivery of information clearly to the public, all facilities and infrastructure must be equipped with an activity information board at the activity's location. The information board contains the name of the activity, the volume of the activity, the budget from the Village Fund and nongovernmental organizations, and the activity's timing. In addition to the activity board at the activity location, information about all Village Fund Facilities and Infrastructure programs must be presented at the village office that can be accessed by the community.

The activity boards and activity information at the village office, which are easily accessible by the community, are implementing the principles of accountability and transparency of village development. The community can freely find out about the facilities and infrastructure program and provide criticism and suggestions to the Village Implementation Team for the perfection of Village Fund management. Following the WM community leader's statement, the Village Government is obliged to provide information to the wider community to provide criticism and suggestions for the perfection of program implementation in Kumelembuai District.

This opinion was greeted positively by the village community in Kumelembuai District, as evidenced by the results of interviews with JL and EW; after the reformation, the government is now very transparent to the community, especially the construction of facilities and infrastructure, among others; Asphalting roads, building embankments, public street lighting, clean water storage buildings, paving blocks on the hamlet axis roads, and road safety fences, the community is directly involved in the implementation of the construction. Non Facilities and Infrastructure Development, including Bimtek for BUMDES management outside the region, Management of Posyandu and Management of BUMDES, and PKK comparative studies. For the 2019 Village Fund, both for the construction of facilities and infrastructure and the construction of non-facilities and infrastructure cannot be used not according to planning because the Village Fund budget was relocated for the Covid Pandemic 19.

According to the Village Secretary Kumelembuai Atas ST and Kumelembuai Dua NL and the activity implementation team, even though the Village Fund budget for 2019 cannot be used for physical and non-physical development activities, every month they make activity reports according to the use of Village Funds for the Covid Pandemic 19 because without activity report, the budget for the following stages is not realized. The interview results indicated that in the implementation of the activity program funded by the Village Fund, the village level managers always reported the progress of the implementation of the activities, both the development of the infrastructure and non-infrastructure activities.

Accountability is the responsibility of the management/administration that is carried out. If this is related to the implementation of activities with the active role of the village community through the implementation of the Village Fund program in Kumelembuai District, the principle of accountability has gradually begun to be applied even though it is not yet perfect, but has shown a firm commitment to carrying out activities. Strengthening village finances is 
carried out to strengthen the pillars of accountability and transparency. Village financial management must be carried out efficiently and effectively, transparently and accountably.

This opinion is supported by the Old Law of the Village of Kumelembuai Dua; in order to ensure the transparency of the management of the Village Fund, we invite the BPD, LPMD, and community leaders once every 3 months to evaluate the implementation of the Village Fund program that I have implemented. In this forum, we ask for input from the community, including information that the community finds in the field as material for improving the evaluation of the Village Fund program's implementation, guiding the community to actively participate in providing input and corrections to the implementation of the Village Fund. In this case, the village government must also respond to community corrections in the forum so that the Village Fund's implementation is perfect.

Permendagri No.113, article 35 of 2014, states that village treasurers must be accountable for village funds through accountability reporting. The village treasurer carries out village fund reporting. According to MW, reporting village funds is by closing the book every month to the sub-district head. The village treasurer carries out accountability for village funds by recording all transactions that occur, then a report is made to the sub-district head, and after that, data input is carried out through the SISKEUDA system. The village treasurer closes the books for general cash books, bank books, and tax auxiliary books. After closing the book, the village treasurer reports to the village head. This activity is one of the supervisory functions carried out by the village head. Based on the results of interviews with VM, TL, LL, DM, JS, $\mathrm{RR}$, and HT, it shows that the village apparatus' understanding of the village treasury's accountability system is quite good even though the treasurers in the villages in Kumelembuai District are only high school graduates.

However, the village treasurer of Kumelembuai District already understands that the village financial system includes all village revenue and expenditure transactions that must be closed. Under Permendagri No. 113 of 2014, book closing must be carried out by the village treasurer every month as a form of supervision by the village head. The village treasurer in Kumelembuai District has closed the book. This is evidenced by the monthly transaction reports to the village head every month. Thus, it can be concluded that in terms of reporting village funds, the village treasurer has a good understanding of its duties and functions and is under Regulation of Permendagri No. 113 of 2014. The village treasurer records revenue, expenditure, and financing of village funds manually to the village head, then after that, it is reported to the district leader or camat for inclusion in the regional financial system.

The Village Fund Implementation Report consists of the first semester report, submitted no later than the end of July of the current year. Furthermore, the year-end semester report is submitted no later than the end of January of the following year. The Village Fund Implementation Realization Report is then submitted to the sub-district head and then forwarded to the district head through the district chief or camat. Generally, the reporting in the villages of Kumelembuai District is good and on time in submitting the Phase I Village Fund Implementation Report, which is August.

Accountability is accountability to the public for every activity carried out by the government, Mardiasmo (26) Accountability is an obligation to convey accountability, performance, and one's actions to parties who have the right and authority to ask for accountability, Bastian (32). Permendagri No.113 of 2014 states that accountability consists of the Village Head submitting the Village Fund Accountability Report to the Regent / Mayor through the camat.

The Village Fund Accountability Report is submitted no later than 1 month after the current fiscal year. The Village Fund Accountability Report consists of activities for receiving 
village funds, village fund expenditures, and financing financed by village funds as stated in the APBDes. In the villages of Kumelembuai District, the Village Fund Accountability Report is reported on time. Permendagri No.113 of 2014 states that accountability consists of the Village Head submitting the Village Fund Accountability Report to the Regent / Mayor through the camat. The Village Fund Accountability Report is contained in the APBDes, consisting of activities for receiving village funds, spending village funds, and financing financed by village funds.

The Village Fund Accountability Report is submitted no later than 1 month after the current fiscal year. In the Kumelembuai District villages, they have reported the Village Fund Accountability Report according to the predetermined time. This information shows that applying the principle of accountability and responsibility in the villages of Kumelembuai District has been good. The Accountability Report's submission to the public has also been made using online media, boards, or billboards. Thus it can be concluded that the accountability of village funds in Kumelembuai District, South Minahasa Regency, is under Permendagri No. 113 of 2014.

\section{Conclusions}

Village Fund planning is the main material for preparing the Village Budget, which is discussed at the village level and agreed upon between the village government, BPD, and the community. APBDesa is a guideline for development activities, community activities, and services to village communities for one year. To comply with the legal principles in the Law of the Republic of Indonesia No.6 of 2014 concerning Villages and PP No. 60 of 2014, which was amended to PP No. 22 of 2015 and PP No.8 of 2016 concerning Village Funds Sourced from the State Budget, the APBDes plan that has been agreed by both parties must be stipulated by a Village Regulation concerning the Village Revenue and Expenditure Budget. Based on the existing regulations, deliberations on development planning, community, and service to the village community will be carried out in one year, after being approved by the BPD as the community and community representatives in Kumelembuai District, South Minahasa Regency.

Village Fund Management in Kumelembuai District, South Minahasa Regency has been implemented in an accountable and transparent manner under the Law of the Republic of Indonesia No.6 of 2014 concerning Villages and PP No.60 2014 concerning Village Funds by holding village development planning deliberations twice in 1 year. However, for 2019, Village Funds' use is not according to planning because Village Funds were relocated for the Covid 19 pandemic.

The results of interviews and field observations based on the 2019 APBDesa Report in Kumelembuai District, the accountability and transparency of the implementation of Village Fund management in Kumelembuai District are under Law No. 6 of 2014 concerning Villages and PP No. 60 of 2014 as amended to PP No. 22 of 2015 and PP No. 8 of 2016 concerning Village Funds sourced from the APBN. In terms of reporting administration, better handling is needed due to the lack of regular administrative documentation. Accountability and transparency require good records to make it easier to trace data.

Administratively, there needs to be improvements and improvements for the perfection of applying the principles of accountability and transparency. Implementing the principles of accountability and transparency will support public confidence in the implementation of the development of village facilities and infrastructure and non-village facilities and 
infrastructure. Although in planning, implementation, reporting, and accountability, the Village Fund is accountable and transparent, it is expected that there must be someone who is an expert in accounting to prepare financial reports.

\section{Acknowledgments}

This paper is supported by the dana PNBP Sam Ratulangi University in Riset Dasar Unggulan Unsrat 2020.

\section{References}

[1] Fatemi M, Behmanesh MR. New Public Management Approach and Accountability. International Journal of Management, Economics and Social Sciences [Internet]. 2012;1(2):42-9. Avaliable: http://www.ijmess.com/volumes/volume-I-2012/issue-II12-2012/full-3.pdf

[2] Hope KR, Chikulo BC. Decentralization, the new public management, and the changing role of the public sector in Africa.Public Management. Public Management [Internet]. 2000;2(1):25-42. Avaliable: https://www.researchgate.net/publication/240240451_Decentralization_the_New_Publi c_Management_and_The_Changing_Role_of_The_Public_Sector_In_Africa

[3] Armacost MH. Foreword. In: The global public management revolution: a report on thetransformation of governance. Kettl, D. F. Washington DC: Brookings Institution; 2000.

[4] Hughes OE. ublic Management and Administration: An Introduction. New York: Palgrave Macmillan; 2003.

[5] Robinson M. From Old Public Administration to the New Public Service: Implications for Public Sector Reform in Developing Countries. Singapore: UNDP for Global Centre for Public Service; 2015.

[6] Grimmelikhuijsen S, Weske U, Bouwman R, Tummers L. Public Sector Transparency. Dalam: James O, Ryzin G van, Jilke S, editor. Experiments in Public Management Research [Internet]. Cambridge: Cambridge University Press; 2017. Avaliable: https://www.researchgate.net/publication/319154450_Public_Sector_Transparency

[7] Gruening G. Origin and theoretical basis of New Public Management. International Public Management Journal [Internet]. 2001;4(1):1-25. Avaliable: https://www.sciencedirect.com/science/article/pii/S1096749401000411

[8] Djamhuri A, Mahmudi M. New Public Management, Accounting Reform, and Institutional Perspective of Public Sector Accounting in Indonesia. Jurnal Bisnis dan Akuntansi [Internet]. 2006;8(3):301-21. Avaliable: http://jurnaltsm.id/index.php/JBA/article/view/240

[9] Islam F. New Public Management (NPM): A Dominating paradigm in public sectors. African Journal of Political Science and International Relations [Internet]. 2015;9(4):141-51. Avaliable: https://www.researchgate.net/publication/289494183_New_Public_Management_NPM A_dominating paradigm in public_sectors

[10] Cuadrado-Ballesteros B, Bisogno M. Public sector accounting reforms and the quality of governance. Public Money and Management [Internet]. 2020;41(2):107-17. Avaliable: 
https://www.tandfonline.com/doi/abs/10.1080/09540962.2020.1724665?journalCode=r pmm20

[11] Al-Marhubi F. The determinants of governance: A cross-country analysis. Contemporary Economic Policy [Internet]. 2008;22(3):394-406. Avaliable: https://onlinelibrary.wiley.com/doi/abs/10.1093/cep/byh029

[12] Mir M, Sutiyono W. Public Sector Financial Management Reform: ACase Study of Local Government Agencies inIndonesia. Australasian Accounting Business and Finance Journal [Internet]. 2013;7(4):97-117. Avaliable: https://ro.uow.edu.au/aabfj/vol7/iss4/7/

[13] Jones LR, Kettl DF. Assessing Public Management Reform in an International Context. International Public Management Review [Internet]. 2003;4(1):1-19. Avaliable: https://journals.sfu.ca/ipmr/index.php/ipmr/article/view/206

[14] Prabowo TJW, Leung P, Guthrie J. Reforms in Public Sector Accounting and Budgeting in Indonesia (2003-2015: Confusions in Implementation. Journal of Public Budgeting, Accounting and Financial Management [Internet]. 2017;29(1):104-37. Avaliable: https://www.emerald.com/insight/content/doi/10.1108/JPBAFM-29-012017-B005/full/html

[15] Rizky HP, Setiawan D. Perkembangan Penelitian Akuntansi Sektor Publik di Indonesia (Public Sector Accounting Research Development in Indonesia). Assets Jurnal Akuntansi dan Pendidikan [Internet]. 2019;8(2):94-116. Avaliable: http://ejournal.unipma.ac.id/index.php/assets/article/view/4647

[16] GOI (Government of Indonesia). Peraturan Pemerintah [The Government Regulation of]: Standar Akuntansi Pemerintahan - Berbasis Kas[Governmental Accounting Standard -Based Cash]. No. 24/2005. Government of Indonesia; 2005.

[17] GOI (Government of Indonesia). Peraturan Pemerintah (The Government Regulation of): Standar Akuntansi Pemerintahan Berbasis Accrual (Governmental Accounting Standard-Based Accrual). No. 71/2010. Government of Indonesia; 2010.

[18] Lubis A. Effectivenesss of Village Fund Management on Increasing Community Welfare with Management Religiosity Behavior as Moderating Variables. Fitrah [Internet]. 2020;66(1):47-64. Avaliable: http://jurnal.iainpadangsidimpuan.ac.id/index.php/F/article/view/2489

[19] Hendrianto W. Improving the Effectiveness of Community Participation in Village Fund Program. Bappenas Working Paper [Internet]. 2019;2(2):213-22. Avaliable: http://workingpapers.bappenas.go.id/index.php/bwp/article/view/41

[20] Imawan SA, Purwanto EA. Governing Village Fund in Indonesia: Is It Eradicating Poverty? Policy and Governancy Review [Internet]. 2020;4(1):14-27. Avaliable: https://iapa.or.id/ejournal/pgr/article/view/169

[21] Nurhakim I, Yudianto I. Implementation of Village Fund Management. Journal of Accounting Auditing and Business [Internet]. 2018;1(2):39-55. Avaliable: http://jurnal.unpad.ac.id/jaab/article/view/18346

[22] Kawung GMV, Mintardjo CMO, Rompas WI, Kojo C, Ogi IJ. Ease of Doing Business in East Indonesian Region: Starting a Business Study in North Sulawesi Province SMEs. Advances in Economics, Business and Management Research. 2019;73(1):197201.

[23] Hood C. A Public Management for All Seasons. Public Administration [Internet]. 1991;69(1):3-9. Avaliable: https://onlinelibrary.wiley.com/doi/abs/10.1111/j.14679299.1991.tb00779.x 
[24] Mahmudi. New Public Management (NPM): Pendekatan Baru Manajemen Sektor $\begin{array}{llll}\text { Publik. Sinergi } & \text { [Internet]. 2003;6(1):69-76. Avaliable: }\end{array}$ https://journal.uii.ac.id/Sinergi/article/view/919

[25] Osborne D, Gaebler T. Reinventing Government: How the Entrepreneurial Spirit is Transforming the Public Sector. New York: Plume; 2003.

[26] Mardiasmo. Otonomi dan Manajemen Keuangan Daerah (Autonomy and Regional Finance Management). Yogyakarta: ANDI; 2012.

[27] Glynn JJ. Public Sector Financial Control and Accounting. Oxford: Blackwell Publisher; 2003.

[28] Halim. Akuntansi Sektor Publik-Akuntansi Keuangan Daerah (Public Sector Accounting-Regional Finance Accounting). Jakarta: Salemba Empat; 2013.

[29] Putera RE. Transparent Regional Financial Management in Tanah Datar District in Implementing Fiscal Decentralization (Pengelolaan Keuangan Daerah yang Transparan di Kabupaten Tanah Datar dalam Melakukan Desentralisasi Fiskal). Sosiohumaniora [Internet]. 2016;18(3):261-9. Tersedia pada: http://jurnal.unpad.ac.id/sosiohumaniora/article/download/6075/6509

[30] Hamied FA. Research Methods: A Guide to First-Time Researchers. Bandung: UPI Press; 2017.

[31] Creswell JW. Qualitative Inquiry and Research Design: Choosing Among Five Tradition. 4 ed. Singapore: Sage Publications Asia Pacific Pte Ltd; 2017.

[32] Bastian I. Akuntansi Untuk Kecamatan dan Desa (Accounting for District and Village). Jakarta: Erlangga; 2015. 